УДК 373.3.091.3

DOI https://doi.org/10.32782/apv/2021.1.13

\title{
Тетяна ОСТАПЙОВСЬКА
}

доиент, доцент кафедри теорії і методики початкової освіти, Волинський національний університет імені Лесі Українки, просп. Волі, 13, м. Луиьк, Волинська обл., Україна, 43025

ORCID: 0000-0003-4404-8586

\section{Ігор ОСТАПЙОВСЬКИЙ}

дочент, дочент кафедри загальної педагогіки та дошкільної освіти, Волинський національний університет імені Лесі Українки, просп. Волі, 13, м. Луцьк, Волинська обл., Украӥна, 43025

ORCID: 0000-0001-7152-4168

Бібліографічний опис статті: Остапйовська, Т., Остапйовський, I. (2021). Використання інтерактивних технологій у підготовці майбутніх педагогів до викладання математики у початковій школі. Acta Paedagogica Volynienses, 1, 73-78, doi: https://doi.org/10.32782/apv/2021.1.13

\section{ВИКОРИСТАННЯ ІНТЕРАКТИВНИХ ТЕХНОЛОГІЙ У ПІДГОТОВЦІ МАЙБУТНІХПЕДАГОГІВДОВИКЛАДАННЯМАТЕМАТИКИУПОЧАТКОВІЙШКОЛІ}

У статті обтрунтовано важсливість технологічного підходу до організації освітнього процесу. Його значимість автори дослідження вбачають в тому, що він дозволить в Новій Украӥнській школі зреалізувати перехід від традииійної пасивної моделі навчально-пізнавальної діяльності школярів до активної. Ініціаторами та провідниками таких змін мають бути як педагоги, так і школярі. Тому на зміну авторитарній педагогіиі має прийти педагогіка партнерства. Комфортне освітнє середовщще, творчий пошук можна забезпечити в прочесі суб'єкт-суб'єктної взаємодіі. Важливим інструментом у ї̈ реалізації є інтерактивні технологї. Майбутній педагог має бути підготовленим до даного виду діяльності. Розкриваючи особливості підготовки майбутніх педагогів до використання інтерактивних технологій в процесі викладання математики у початковій школі, у статті обтрунтовано методологічні підходи та умови, які забезпечують даний процес. Також зроблено висновки та визначено перспективи подальших наукових досліджень.

Ключові слова: інтерактивні технології, підготовка майбутніх фахівців до викладання математики у початковій школі, методологічні підходи, педагогічні умови, освітній процес, заклад вищої освіти.

\section{Tetiana OSTAPIOVSKA}

Associate Professor, Senior Lecturer at the Department of Theory and Methods of Primary Education, Lesya Ukrainka Volyn National University, 13 Voli ave., Lutsk, Volyn region, Ukraine, 43025

ORCID: 0000-0003-4404-8586

\section{Ihor OSTAPIOVSKYI}

Associate Professor, Senior Lecturer at the Department of General Pedagogy and Preschool Education, Lesya Ukrainka Volyn National University, 13 Voli ave., Lutsk, Volyn region, Ukraine, 43025

ORCID: 0000-0001-7152-4168

To cite this article: Ostapiovska, T. \& Ostapiovskyi, I. (2021). Vykorystannia interaktyvnykh tekhnolohii u pidhotovtsi maibutnikh pedahohiv do vykladannia matematyky u pochatkovii shkoli [The use of interactive technologies in preparing future teachers for teaching mathematics in primary school]. Acta Paedagogica Volynienses, 1, 73-78, doi: https://doi.org/10.32782/apv/2021.1.13

\section{THE USE OF INTERACTIVE TECHNOLOGIES IN PREPARING FUTURE TEACHERS FOR TEACHING MATHEMATICS IN PRIMARY SCHOOL}

The importance of the technological approach to the organization of the educational process was substantiated in the article. The authors of the article see its significance in the fact that it will allow the New Ukrainian school to implement the transition from the traditional passive model of educational and cognitive activities of schoolchildren to active. 
Both teachers and students should be the initiators and leaders of such changes. Therefore, authoritarian pedagogy must be replaced by the pedagogy of partnership. A comfortable educational environment, creative search can be provided in the process of subject-subject interaction. An important tool in its implementation is interactive technologies. The future teacher must be prepared for this type of activity. Revealing the peculiarities of training future teachers to use interactive technologies in the process of teaching mathematics in primary school, were substantiated the methodological approaches and conditions that were provide this process in the article. Conclusions are also were made and prospects for further research were determined.

Key words: interactive technologies, preparation of future specialists for teaching mathematics in primary school, methodological approaches, pedagogical conditions, educational process, institution of higher education.

Починаючи із середини минулого століття у педагогічній науці та освітянській практиці актуальною є проблема технологізації освітнього процесу. Її впровадження дозволяє не лише алгоритмізувати діяльність педагогів та школярів, досягнути діагностовано запланованого результату, але здійснити перехід від традиційної пояснювально-ілюстративної до активної та інтерактивної моделі організації навчального процесу. Ця ідея є співзвучною із Концепцією Нової української школи, пріоритетними завданнями якої $є$ наблизити навчальний процес до потреб дитини, сформувати ключові компетентності, підготувати ii до життя в умовах мінливого середовища [1]. Саме тому важливою науковою проблемою $є$ підготовка майбутніх вчителів до використання інтерактивних технологій в процесі викладання математики у початковій школі.

Теоретичні та прикладні аспекти інтерактивних технологій розкрито у роботах вітчизняних дослідників. Над їх розв'язанням працювали О. Антонова, В. Бондар, О. Бульвінська, С. Гончаренко, Н. Воскресенська, О. Мороз, О. Онищук, І. Остапйовський, О. Острянська, О. Полякова, О. Пометун, Л. Пироженко, О. Савченко, В. Семиченко, М. Сметанський, В. Сластьонін, Л. Хомич та ін.

Аналіз наукових джерел засвідчує англійське походження терміну «interact», де «inter»- взаємний i «act»- діяти. Тобто, інтерактивний - здатний до взаємодії, співпраці, діалогу, полілогу. Таким чином інтерактивна модель навчання передбачає постійну взаємодію між усіма учасниками освітнього процесу педагога зі школярами, школярів $з$ школярами. За такої моделі домінуючими $є$ не розповідь пояснення, представлення «готових знань», а ділові та рольові ігри, дискусії, мозковий штурм, фронтальне опитування, круглий стіл, дебати та ін. Активність, творчий пошук, комфортні умови для здобуття і засвоєння знань дозволяють кожному школяреві відчувати свою успішність, інтелектуальну спроможність, робити освітній процес більш досконалим.

Влучно, на нашу думку, сутність навчання із використанням інтерактивних технологій розкрито українськими науковцями О. Пометун та Л. Пироженко [2]. Характеризуючи даний вид діяльності вони зазначають, що здобуття та оволодіння знаннями передбачає постійну активну взаємодію, співнавчання, взаємонавчання (колективне, групове навчання у співпраці). Завдяки ефекту новизни та оригінальності інтерактивних методів, за правильної їх організації зростає інтерес до навчання, внутрішня мотивація навчання, що сприяє його ефективності. Організація інтерактивного навчання передбачає моделювання життєвих ситуацій, використання рольових ігор, спільне вирішення проблеми на основі аналізу обставин та відповідної ситуації. Воно ефективно сприяє формуванню навичок і вмінь, виробленню цінностей, створенню атмосфери співробітництва, взаємодії, дає змогу педагогу стати справжнім лідером дитячого колективу [2, с. 9].

Описаний вище ефект забезпечується дотриманням принципів педагогіки партнерства, зміни ролі вчителя із ретранслятора знань у організатора, консультанта, фасилітатора, коуча. Розумінням педагогами, що інтерактивне навчання є сукупністю технологій, які включають чітко спланований очікуваний результат навчання, окремі методи та прийоми, які стимулюють процес пізнання, розумові і навчальні процедури, за допомогою яких можна досягнути запланованих результатів.

Виходячи із мети навчального заняття та форми організації навчально-пізнавальної діяльності школярів, виділяють чотири групи технологій інтерактивного навчання:

- інтерактивні технології кооперативного навчання;

- інтерактивні технології колективно-групового навчання;

- технології ситуативного навчання; 
- технології опрацювання дискусійних питань [2, с. 33].

Ознайомлення та підготовку майбутніх педагогів до використання інтерактивних технологій в процесі викладання математики у початковій школі здійснювали із використанням компетентнісного, особистісно-орієнтованого, системного, синергетичного, діяльністного, міждисциплінарного підходів та дотриманням певних педагогічних умов.

В роботі зі студентами використовували компетентнісний підхід. Його вибір був продиктований тим, що даний підхід грунтується на передбаченні і формуванні професійних та особистісних якостей, організаторських здібностей, уміння приймати рішення і брати на себе відповідальність, оволодінням необхідними комунікативними якостями, здатності оцінювати соціальні процеси, визначити роль і місце своєї професійної діяльності, знаходити шляхи іiі удосконалення. Реалізація компетентнісного підходу у вищій школі передбачає навчання дією. Суть компетентнісного підходу полягає ще й в тому, що студенти працюють над набуттям i розширенням самостійного досвіду розв'язання реальних завдань, вчаться знаходити раціональні рішення i розвивають здібності адаптуватися до будь-якої незвичної ситуації. В контексті навчання дією студенти вчаться критично мислити, працюють не зі штучними, а 3 реальними проектами, навчаються як у викладача, так і один в одного, вибирають і приймають різні рішення у конкретних реальних професійних ситуаціях.

Вибір особистісно-орієнтованого підходу зумовлений тим, що навчання студіюючої молоді у відповідності з даним підходом спрямоване на розкриття індивідуальних пізнавальних можливостей кожного студента; розвиток індивідуальних задатків та здібностей майбутніх фахівців; допомогу в самопізнанні, самоактуалізації, самореалізації, самовизначенні; формуванні культури життєдіяльності, яка дає можливість продуктивно будувати власне життя.

В процесі підготовки майбутніх педагогів до використання інтерактивних технологій на уроках математики в початковій школі нами також творчо використовувалося системний, синергетичний, діяльнісний та міждисциплінарний підходи.
У виборі синергетичного та системного підходів керувалися тим, що синергетична узгодженість об'єктивних і суб'єктивних чинників дає змогу спрогнозувати мету, завдання, зміст, форми i методи науково-методичної роботи зі студентами, координувати діяльність, своєчасно вносити корективи, вибудовувати діяльність на демократичних засадах. Згідно i3 системним підходом процес формування готовності до застосування інтерактивних технологій на уроках математики вивчається як системне явище 3 урахуванням усіх факторів впливу на особистість: внутрішніх і зовнішніх; головних і другорядних; полі- та монофункціональних тощо, виходячи з принципів інтеграціï, цілісності, комплексного аналізу. Системний аналіз процесу формування готовності до застосування інтерактивних технологій на уроках математики передбачає єдність педагогічної теорії та практики; соціального, особистісного і діяльнісного в розвитку цього утворення.

Діяльнісний підхід спирається на базовий методологічний принцип єдності свідомості і діяльності. У процесі практичної діяльності закріплюються головні математичні знання i в поєднання 3 природними задатками та розвитком інтелекту, створюються певні умови для самореалізації особистості.

Міждисциплінарний підхід є об’єктивною єдністю всіх наукових дисциплін, що вивчаються (математики, методики викладання математики, педагогіки та психології), своєрідною межею комплексного підходу. Це науковопедагогічна новація, що породжує здатність побачити, розпізнати, сприйняти те, що є недоступним в межах окремо взятої дисципліни з їі специфічним, вузькоорієнтованим об'єктом, предметом і методами дослідження. Інтеграція знань цих наук забезпечує цілісний підхід до досліджуваної проблеми.

Формування готовності майбутніх учителів початкової школи до застосування інтерактивних технологій на уроках математики ми розглядаємо як цілісний процес, результативність якого залежить від спрямованості змісту, форм і методів теоретичної та практичної підготовки. Створенню цілісної системи такої підготовки сприяє саме наявність сукупності оптимальних педагогічних умов.

Педагогічними умовами успішного формування готовності майбутніх учителів математики 
до застосування інтерактивних технологій на уроках математики є:

1. Підвищення рівня методичної підготовки викладачів щодо інтерактивних технологій навчання (опанування викладачами знаннями про сутність, принципи, зміст інтерактивних технологій навчання, здатність організувати роботу на заняттях із застосуванням інтерактивних технологій). Ця умова $є$ необхідною, оскільки приклад викладача, досвідченого педагога, його модель-матриця поведінки впливає на формування професійної діяльності майбутнього вчителя початкової школи. Ця умова має великий вплив на формування мотиваційноцільового компоненту готовності студентів до застосування інтерактивних методик на уроках початкової школи. Вона реалізується за відповідної взаємодії викладача і студента, якщо емоційно-оцінювальна діяльність пронизує всі елементи навчання й безпосередньо передбачена у результатах навчання. Викладач має оперувати способами навчальної діяльності, формами спілкування тощо, які б надавали можливість формувати у студентів мотивацію до фахової інтерактивної діяльності, інтерес до неї, позитивне особисте ставлення до інтерактивного навчання та прагнення до накопичення відповідного педагогічного досвіду. Саме тому одна 3 основних вимог до застосування інтерактивних технологій - власний досвід участі викладача в групових інтерактивних вправах. Для того, аби підготувати його до інтерактивного викладання, треба дати йому можливість отримати такий досвід. Це можливо за рахунок спеціального навчання - проходження всіма без винятку викладачами спеціальних семінарів тренінгів або баркемпів.

2. Включення у навчальний план підготовки майбутніх фахівців навчальних дисциплін, окрім навчальних дисциплін «Технології освітнього процесу в НУШ», «Сучасні педагогічні технології навчання математики у початковій школі» [3], предмету «Інтерактивні технології навчання на уроках математики в початковій школі». Дана педагогічна умова спрямована на посилення когнітивного компоненту готовності і систематизує знання студентів про інтерактивні технології, про рефлексію, про будову уроку математики із застосуванням інтерактивних технологій навчання. Це дозволить посилити зміст математичних дисциплін.
3. Розвиток дослідницьких умінь студентів у позанавчальній діяльності. Ця педагогічна умова є об'єднанням операційного та рефлексивного компонентів готовності, тобто дозволяє набути студентам практичних навичок та вміти оцінити свої вміння. Різновидом позанавчальної діяльності є зокрема, дослідницька діяльність: систематичне дослідження - постановка проблеми, висування і перевірка гіпотез, генерація ідей тощо. Психолого-дидактичними засобами реалізації цього підходу є розвиток творчого і критичного мислення, формування досвіду та інструментарію навчально-дослідницької діяльності, рольове та імітаційне моделювання, пошук i визначення особистісних смислів тощо» [4, с. 39]. Така педагогічна умова $€$ практико-орієнтованою складовою готовності до застосування інтерактивних технологій і включає в себе розширення сфери математичної підготовки у різних формах позанавчальної роботи, зокрема студентського математичного гуртка. В ході опитування, студенти факультету педагогічної освіти та соціальної роботи відмітили, що найчастіше дослідницькою роботою вони займаються в ході виконання курсових робіт.

4. Посилення змісту педагогічної практики, зокрема, збагачення іiі проведенням уроків iз використанням інтерактивних технологій. Відомо, що оволодіння педагогічною діяльністю та формування готовності до неї можливі лише за умови взаємопроникнення теоретичної (когнітивної) та практичної (операційна) підготовки, адже жоден 3 компонентів готовності не можна сформувати лише в умовах освітнього процесу в аудиторіях закладу вищої освіти. У Положенні про проведення практики студентів Волинського національного університет імені Лесі Українки, вказано, що метою практики $\epsilon$ закріплення теоретичних знань, отриманих студентами під час навчання, формування у них професійних умінь за відповідною освітньопрофесійною програмою для прийняття самостійних рішень у конкретних умовах фахової діяльності [5]. Педагогічна практика розв'язує наступні завдання: забезпечує фундаментальний науковий всебічний розвиток особистості; впливає на психолого-педагогічну підготовку; сприяє виробленню умінь та навичок професійної діяльності; формує розуміння необхідності застосовувати інтерактивні технології на 
уроках математики; розвиває здібності спілкуватися з дітьми, колегами, батьками.

5. Використання інтерактивних технологій в процесі традиційних форм організації освітнього процесу в закладах вищої освіти. В університеті, як вищому навчальному закладі, традиційними формами організації навчального процесу є лекційні, семінарські, практичні, лабораторні заняття. Реалізовуючи дану педагогічну умову, пропонуємо, як приклад, використання інтерактивних технологій в процесі проведення лекційного заняття на тему «Дроби». Як варіант розкриття цієї теми обрано проблемно-дослідницьку лекцію. Метою такої лекції є розвиток творчих здібностей студентів, аналітико-синтетичних умінь; умінь зіставляти, порівнювати, узагальнювати, систематизувати навчальний матеріал, абстрагуватися. Проведення такої лекції включає проблемне питання, яке передбачає використання дослідницько-пошукової діяльності студентів. Викладач керує процесом пізнання, дослідницькою діяльністю студентів 3 розв'язання проблемного питання, намагаючись викликати внутрішню потребу студентів розв'язати проблемне завдання; стати активними, ініціативними, динамічними дослідниками, співавторами процесу здобуття «нових» знань. Цей вид лекції привчає студентів розмірковувати, самостійно здобувати знання, самостійно шукати способи вирішення проблемного питання, висувати гіпотези та перевіряти ïх цінність, сприяє формуванню гнучкості мислення, здатності розглянути питання під різним кутом зору, усвідомленню суті досліджуваного проблемного питання.

Початок лекційного заняття розпочинається із використання інтерактивної технології «Мікрофон». Метою технології передбачалося, щоб студенти по черзі висловлювали свою думку щодо визначення поняття «Дроби»:

1. Дріб - це представлення чисел або математичних величин у вигляді результату операції ділення.

2. Дробом називають частку від ділення двох виразів, записану за допомогою дробової риски.

Таку технологію можна застосовувати на будь-якій лекції, це дає можливість активізувати пізнавальну діяльність студентів, привернути їхню увагу до складних або проблемних питань у навчальному матеріалі.
Наступним етапом було повідомлення інформації студентам по визначеній темі. Найбільш доцільним було використання такої технології, як «Навчаючи-вчуся», так як за іiі допомогою можна швидко і цікаво повідомити великий блок матеріалу.

Зміст завдання полягав у тому, що студенти готували картки з фактами, що стосуються теми лекції, кілька хвилин вони читали дану інформацію. Після цього кожен учасник виступав із своїм повідомленням. Це дало можливість студентам поділитися своїм фактом і самому отримати інформацію від іншого учасника. Студенти отримують загальну картину понять і фактів щодо заданої теми, у них виникають певні запитання, що підвищує інтерес до навчання.

Інформація складалась із кількох речень:

1. «Ознайомлення учнів 3 дробовими числами у формі звичайних дробів проводиться у зв'язку з вивченням множення і ділення багатоцифрових чисел і грунтується на уявленнях, знаннях, вміннях і навичках, вироблених учнями при ознайомленні з частками величин (числа)».

2. «Методика ознайомлення 3 простими дробами грунтується в основному на конкретних образах часток величини, на практичному отриманні тої чи іншої частки, а потім і дробу, шляхом ділення предметів, геометричних фігур на потрібне число рівних частин тощо. Тут не допускається спроба формально дати визначення цих понять».

3. «В залежності від підготовки класу до вивчення теми «Дроби» може бути відведено 7-8 уроків. Причому до уроків, на яких діти знайомляться 3 новим для них матеріалом - дробами, включається (50\%) матеріал, пов'язаний з оволодінням техніки обчислень, розв'язуванням задач».

Такий метод $\epsilon$ ефективним у використанні i часто застосовується при вивченні нової інформації.

За цією ж темою було проведено практичне заняття. Усне опитування проводилось із використанням технології «Мікрофон». Студенти швидко, лаконічно і по черзі відповідали на такі запитання: «Які числа називаються дробовими? Що означає чисельник дробу? Що означає знаменник дробу? Як знайти дріб від числа?» Запитання не коментувались і не оцінювались. 
Розв'язування вправи на обчислення дробового виразу здійснювалось у групах. Це дало можливість студентам згрупуватись, встановити позитивний контакт між членами групи. Студенти чітко мали визначити між собою, хто яку дію має виконати. Таким чином, завдання було швидко і правильно виконане.

Отже, використання інтерактивних технологій дозволяє не лише глибоко і грунтовно оволодіти навчальним матеріалом, а й підготувати майбутніх педагогів до творчого використання інтерактивних технологій в процесі викладання математики у початковій школі. Проведене нами дослідження також дозволило окреслити перспективи подальших наукових пошуків. Ними $є$ педагогічні умови використання інтерактивних технологій в організації позакласної та позашкільної діяльності молодших школярів із математики.

\section{ЛІТЕРАТУРА:}

1. Нова українська школа : Концепція засади реформування середньої школи. URL: www.kmu.gov.ua/storage/ app/media/reforms/ukrainska-shkola-compressed.pdf

2. Пометун О. Сучасний урок: інтерактивні технології навчання : наук.-метод. Посіб. К. : А.С.К., 2004. 192 с.

3. Навчальний план спеціальності 013 Початкова освіта, бакалавр, денна форма, 2020. URL: https://volnu-my.sharepoint.com/personal/pedagogical_vnu_edu_ua/_layouts/15/onedrive

4. Кларін М. Формування ключових компетентностей на уроці математики в 2 класі. Початкова школа. 2015. № 12. C. 39-41.

5. Положення про проведення практики студентів Волинського національного університет імені Лесі Українки. URL: https://vnu.edu.ua/sites/default/files/2020

\section{REFERENCES:}

1. Nova ukrainska shkola: Kontseptsiia zasady reformuvannia serednoi shkoly. [New Ukrainian school: The concept of the principles of secondary school reform]. Retrieved from: //www.kmu.gov.ua/storage/app/media/reforms/ukrainskashkola-compressed.pdf [in Ukrainian]

2. Pometun O., Pypozhenko L. (2004) Cuchacnyi upok: intepaktyvni texnolohii navchannia [Modern lesson: interactive learning technologies]. Kyiv: A.S.K [in Ukrainian]

3. Navchalnyi plan spetsialnosti 013 Pochatkova osvita, bakalavr, denna forma, 2020 [Curriculum of specialty 013 Primary education, bachelor, full-time, 2020]. Retrieved from: https://volnu-my.sharepoint.com/personal/ pedagogical_vnu_edu_ua/_layouts/15/onedrive [in Ukrainian]

4. Klarin M. (2015) Formuvannia kliuchovykh kompetentnostei na urotsi matematyky v 2 klasi [Formation of key competencies in mathematics lessons in 2nd form] Pochatkova shkola. 12. 39-41 [in Ukrainian]

5. Polozhennia pro provedennia praktyky studentiv Volynskoho natsionalnoho universytet imeni Lesi Ukrainky [Regulations on conducting internships for students of Lesya Ukrainka Volyn National University]. Retrieved from: https://vnu.edu.ua/sites/default/files/2020. 